\begin{tabular}{|c|c|}
\hline Title & $\begin{array}{l}\text { Labour market reform, welfare and urban unemployment in a small open } \\
\text { economy }\end{array}$ \\
\hline \multicolumn{2}{|l|}{ Sub Title } \\
\hline Author & Chaudhuri, Sarbajit \\
\hline Publisher & Keio Economic Society, Keio University \\
\hline Publication year & 2006 \\
\hline Jtitle & Keio economic studies Vol.43, No.2 (2006. ) ,p.1- 17 \\
\hline \multicolumn{2}{|l|}{ JaLC DOI } \\
\hline Abstract & $\begin{array}{l}\text { The paper examines the aptness of labour market reform in a developing country } \\
\text { using a three-sector Harris-Todaro model with agricultural dualism and a } \\
\text { nontraded final commodity. The paper, contrary to the common belief, finds that } \\
\text { liberalization in the labour market may be desirable from the view points of both } \\
\text { social welfare and unemployment problem. This theoretical framework may be } \\
\text { useful in explaining as to why labour market reform should be regarded as an } \\
\text { integral component of the package of liberalized economic policies in the } \\
\text { countries in transition. }\end{array}$ \\
\hline \multicolumn{2}{|l|}{ Notes } \\
\hline Genre & Journal Article \\
\hline URL & $\begin{array}{l}\text { https://koara.lib.keio.ac.jp/xoonips/modules/xoonips/detail.php?koara_id=AA002 } \\
\text { 60492-20060002-0001 }\end{array}$ \\
\hline
\end{tabular}

慶應義塾大学学術情報リポジトリ(KOARA)に掲載されているコンテンツの著作権は、それぞれの著作者、学会または出版社/発行者に帰属し、その 権利は著作権法によって保護されています。引用にあたっては、著作権法を遵守してご利用ください。

The copyrights of content available on the KeiO Associated Repository of Academic resources (KOARA) belong to the respective authors, academic societies, or publishers/issuers, and these rights are protected by the Japanese Copyright Act. When quoting the content, please follow the Japanese copyright act. 


\title{
LABOUR MARKET REFORM, WELFARE AND URBAN UNEMPLOYMENT IN A SMALL OPEN ECONOMY
}

\author{
Sarbajit CHAUDHURI \\ Department of Economics, University of Calcutta, \\ Kolkata, India
}

First version received November 2005; final version accepted September 2006

\begin{abstract}
The paper examines the aptness of labour market reform in a developing country using a three-sector Harris-Todaro model with agricultural dualism and a nontraded final commodity. The paper, contrary to the common belief, finds that liberalization in the labour market may be desirable from the view points of both social welfare and unemployment problem. This theoretical framework may be useful in explaining as to why labour market reform should be regarded as an integral component of the package of liberalized economic policies in the countries in transition.
\end{abstract}

Keywords: Labour market reform, unionized wage, rural-urban migration, welfare, urban unemployment, general equilibrium.

JEL Classification Number: F2, F21, O17.

\section{INTRODUCTION}

The past two decades have seen focal changes in the economic policies of the developing countries which have adopted economic liberalization as their development strategy. Liberalization involves both inflow of foreign capital as well as reduction of protection of domestic industries and integrating the domestic market with the world market. Liberalized policies are designed at increasing the role of the private sector, reducing the extent of government controls over various aspects of the domestic economy, removing factor market distortions and opening up the economy to trade and foreign investment.

Although the pace of economic reforms has been different across countries, radical measures for reducing tariff barriers and completely doing away with non-tariff barriers to ensure freer global trade have already been undertaken in manufacturing commodities. Sweeping changes have been made to lift controls over domestic economy and many key sectors, hitherto reserved for public sector, have completely been opened up

Acknowledgements. The author is indebted to an anonymous referee of this journal for his/her interesting and constructive comments on an earlier version of the paper. However, the usual disclaimer applies. E-mail: sarbajitch@yahoo.com, sceco@caluniv.ac.in

Copyright (C) 2006, by the Keio Economic Society 
for private investment including foreign investment. Revolutionary changes have been made in exchange rate and tax policies. Financial sector has also been liberalized. Many of the developing countries including India are now seriously thinking in terms of implementing reforms in the labour market which has been a crucial aspect in the reform agenda.

There have been tremendous pressures on the governments of the developing countries both from domestic and foreign investors to liberalize the labour markets as rigid labour laws are serious impediments to their profitability. MNCs as well as domestic capitalists make investment decisions solely for maximization of their profits. Trade union activities ensuring stipulations about working hours, pay rise, bonus, retirement benefits, and any other benefits which are minimum requirements of the workers for a human living and strikes and lock-outs hamper production and raise the costs of production of the investors thereby seriously affecting their profitability. It is argued that if wages are high and investors are unable to retrench redundant workers, close down unviable units and relocate their businesses within the economy, they would not be able to compete effectively with other countries where labour laws are relatively flexible. Consequently, they would be forced to pull their shutters down which will lead to widespread open unemployment. According to this line of argument labour market reforms should get top priority even for the betterment of the working class as a whole given the grave unemployment situations in the developing countries.

It is needless to point out that liberalization of labour laws is a very much politically sensitive issue. It is apprehended by the trade unions that any relaxation of labour laws will lead to general wage reductions of the poorer groups of the working population engaged in different sectors of the economy and accentuate wage inequality and the unemployment problem. As labour markets take a longer time to adjust vis-à-vis the capital markets, the working class has to face substantial adjustment costs, especially at the early stages of labour market reforms.

Under the circumstances, it would be an interesting theoretical exercise to analyze the effects of labour market reform on the competitive wage, welfare and the unemployment problem in a developing economy and to examine whether the general apprehensions about the adverse consequences of labour market liberalization have any solid theoretical fundamentals. The present addresses these issues using a three sector general equilibrium model of Harris-Todaro (hereafter HT) type with agricultural dualism and a non-traded final commodity.

Agricultural dualism is a common symptom of the developing countries. The distinction between advanced and backward agriculture can be made on the basis of inputs used, economies of scale, efficiency and elasticity of substitution. Many of the farmers in the agricultural sector of a developing economy stick to old and unscientific methods of cultivation although in other parts of the economy the introduction of the so called 'Green Revolution' technology brought about revolutionary changes with respect to production technologies and modern inputs use and the increase in factor productivity. Although, Green Revolution has modernized agricultural technology, it is limited only 
to a few parts of a developing economy and only rich (large) farmers have been benefited from it. The small and marginal farmers continue to depend on rain-fed backward agricultural technique. Therefore, the adoption of the Green Revolution technology has led to an increase in the extent of agricultural dualism in a developing economy.

The existence of non-traded goods, the prices of which are determined domestically by demand-supply forces, is another essential feature of a developing economy. The non-traded goods may be either intermediaries or final commodities. There are many final agricultural commodities, which are consumed domestically and are produced mainly by small and marginal farmers using traditional techniques of production. On the other hand, all commercial crops and some of the foodgrains are produced by large cultivators using advanced techniques. A lion's shares of these commodities are exported to foreign countries and their prices are determined internationally.

The present paper shows that a reduction in the unionized urban wage does not necessarily worsen welfare and aggravate the problem of urban unemployment in the developing countries. In fact, such a policy of labour market reform may not only increase the non-unionized wage of the common workers but also improve national welfare and the unemployment scenario under reasonable conditions. These results are extremely crucial because the policymakers are hesitating in implementing measures to curb union power on the apprehension that any such attempt would be vehemently opposed by trade unions and opposition political parties. But the analysis of the present paper shows that the concerns of the trade unions about the possible consequences of labour market liberalization do not have sound theoretical foundation. Labour market reform might not only increase the competitive informal wage and the level of employment but also lead to an improvement in national welfare.

\section{THE MODEL}

We consider a small open dual economy, which is broadly divided into an urban sector and a rural sector. The rural sector is further subdivided into two sub-sectors so that in all we have three sectors in our economy. Of the two rural sectors, there is an advanced agricultural sector (sector 1) which produces its output using labour and land-capital as inputs. This is the export sector of the economy. The other sector within the rural sector, we call it the backward agricultural sector, produces a non-traded final commodity using the same two inputs. The input 'land-capital' is broadly conceived to include durable capital equipments of all kinds. ${ }^{1}$ It is sensible to assume that sector 2 is more labour intensive than sector 1 . On the other hand, the urban sector (sector 3 ) produces a manufacturing commodity with the help of labour and capital. This is the import-competing sector of the economy and is protected by an import tariff. Capital is specific to sector 3 while land-capital is completely mobile between the two rural sectors. Labour is perfectly mobile between sectors 1 and 2 but is imperfectly mobile between the urban and the rural sectors. The urban sector faces an imperfect labour market in the form of a unionized labour market where workers receive a contractual

\footnotetext{
1 See Bardhan (1972) in this context.
} 
(unionized) wage, $W^{*}, 2,3$ while the wage rate in the two rural sectors, $W$, is market determined with $W^{*}>W$. The two wage rates are related by the Harris-Todaro (1970) condition of migration equilibrium where the 'pected urban wage equals the rural wage rate. Production functions exhibit constant 1 ns to scale with diminishing marginal productivity to each factor. Commodity 1 is chosen as the numeraire.

The following symbols will be used in the formal presentation of the model.

$L=$ fixed number of workers in the economy;

$N=$ economy's given endowment of land-capital;

$K=$ capital stock of the economy;

$L_{U}=$ level of urban unemployment;

$X_{i}=$ output of the $i$ th sector, $i=1,2,3$;

$j_{i}=$ amount of the $j$-th input employed in the $i$-th industry, $j=L, N, K$; and, $i=1,2,3$;

$a_{L i}=$ labour-output ratio in the $i$ th sector, $i=1,2,3$;

$a_{N i}=$ vland capital-output ratio in the $i$ th sector, $i=1,2$;

$a_{K i}=$ capital-output ratio in sector 3 ;

$\theta_{j i}=$ distributive share of the $j$-th input in the $i$-th industry, $j=L, N, K$; and, $i=1,2,3$;

$\lambda_{j i}=$ proportion of the $j$-th input employed in the $i$-th industry, $j=L, N, K$; and, $i=1,2,3$;

$P_{1}=1$ (commodity 1 is the numeraire);

$P_{3}=$ world price of good 3;

$P_{2}=$ domestically determined price of good 2 ;

$P_{3}^{*}=$ domestic or tariff-inclusive price of commodity 3 ;

$t=$ ad-valorem rate of tariff on the import of commodity 3 ;

$W=$ competitive wage rate in the two agricultural sectors;

$W^{*}=$ institutionally given wage rate in the manufacturing sector;

$R=$ rate of return to land-capital;

$r=$ rate of return to capital;

$D_{i}=$ consumption demand for the $i$ th final commodity, $i=1,2,3$;

2 Assuming that each urban sector firm has a separate trade union, the unionized wage function may be derived as a solution to the Nash bargaining game between the representative firm and the representative union in the industry. This function has been derived in details in Chaudhuri (2003).

3 The firms in the urban (manufacturing) sector have well-organized trade unions. One of the most important roles of the labour unions is to bargain with the respective employers in respect of the betterment of the working conditions. Through offer of negotiation, threat of strike, actual strike etc. they exert pressure on the employers (firms) in order to secure higher wages, reduced hours of work, share in profits and other benefits. Bhalotra (2002) has noted that in India before the initiation of economic reforms organized workers in large firms were been able to reap wages higher than the supply price of labour due to the job security and minimum wage legislations. The higher the bargaining strength of the unions the higher is expected to be the extent of benefits that can be wrested through collective-bargaining. Now if the government undertakes measures e.g. partial or complete ban on resorting to strikes by the trabe unions, reformation of employment security laws to curb union power, the unions' power to mark up wages over the supply of labour decreases. Therefore, the consequence would be a fall in the unionized wage. Thus, labour market reform in the present context may be captured in terms of an exogenous reduction in the unionized wage. 
$E_{P 2}^{2}=$ own price elasticity of demand for commodity 2 ;

$E_{Y}^{2}=$ income elasticity of demand for commodity 2 ;

$U=$ social utility;

$Y=$ national income at domestic prices;

$m_{3}=$ marginal propensity to consume commodity 3 ;

$M=$ import demand for commodity 3 ;

$\wedge=$ proportional change.

The general equilibrium structure of the model is as follows.

Given the assumption of perfectly competitive markets the usual price-unit cost equality conditions relating to the three sectors of the economy are given by the following three equations, respectively.

$$
\begin{gathered}
W a_{L 1}+R a_{N 1}=1 \\
W a_{L 2}+R a_{N 2}=P_{2} \\
W^{*} a_{L 3}+r a_{K 3}=(1+t) P_{3}
\end{gathered}
$$

Full utilization of land-capital and capital imply the following two equations, respectively.

$$
\begin{gathered}
a_{N 1} X_{1}+a_{N 2} X_{2}=N \\
a_{K 3} X_{3}=K
\end{gathered}
$$

There is unemployment of labour in the urban sector. The labour endowment equation of the economy is given by the following.

$$
a_{L 1} X_{1}+a_{L 2} X_{2}+a_{L 3} X_{3}+L_{U}=L
$$

In a Harris-Todaro framework the labour allocation mechanism is such that in the labor market equilibrium, the rural wage rate, $W$, equals the expected wage income in the urban sector. Since the probability of finding a job in the urban manufacturing sector is $\left(a_{L 3} X_{3} /\left(a_{L 3} X_{3}+L_{u}\right)\right)$ in the present case, then the expected wage in the manufacturing sector is $\left(W^{*} a_{L 3} X_{3} /\left(a_{L 3} X_{3}+L_{u}\right)\right)$. Therefore, the rural-urban labour allocation mechanism is expressed as

$$
\left(W^{*} a_{L 3} X_{3} /\left(a_{L 3} X_{3}+L_{u}\right)\right)=W,
$$

or equivalently,

$$
\left(W^{*} / W\right) a_{L 3} X_{3}+a_{L 2} X_{2}+a_{L 1} X_{1}=L
$$

The demand for the non-traded final commodity is given by

$$
\begin{array}{r}
D_{2}=D_{2}\left(P_{2}, P_{3}^{*}, Y\right) \\
(-)(+)(+)
\end{array}
$$


We assume that commodity 2 is a normal good with negative and positive own price and income elasticities of demand, respectively. The cross-price elasticity is positive. So, we have

$$
\begin{gathered}
E_{P 2}^{2}=\left(\left(\partial D_{2} / \partial P_{2}\right)\left(P_{2} / D_{2}\right)\right)<0 ; E_{Y}^{2}=\left(\left(\partial D_{2} / \partial Y\right)\left(Y / D_{2}\right)\right)>0 ; \text { and }, \\
E_{P 3^{*}}^{2}=\left(\left(\partial D_{2} / \partial P_{3^{*}}\right)\left(P_{3^{*}} / D_{2}\right)\right)>0 .
\end{gathered}
$$

The demand-supply equality condition for commodity 2 is $D_{2}=X_{2}$. Using (8), this can be rewritten as follows.

$$
X_{2}=D_{2}\left(P_{2}, P_{3}^{*}, Y\right)
$$

The demand for the importables (commodity 3 ) and the volume of import are given by the following two equations, respectively.

$$
\begin{gathered}
D_{3}=D_{3}\left(P_{2}, P_{3}^{*}, Y\right) ; \text { and } \\
(+)(-)(+) \\
M=D_{3}\left(P_{2}, P_{3}^{*}, Y\right)-X_{3}
\end{gathered}
$$

The national income of the economy at domestic prices is given by

$$
Y=X_{1}+P_{2} X_{2}+P_{3}^{*} X_{3}+t P_{3} M
$$

or equivalently,

$$
Y=W L+R N+r K+t P_{3} M
$$

In equation (12.2), $W L$ gives the total wage income of the workers employed in the different sectors of our Harris-Todaro economy. ${ }^{4} \mathrm{RN}$ is the rental income from landcapital. $r K$ is the capital income. Finally, $t P_{3} M$ is the tariff revenue earned by the government from import of commodity 3 , which is handed over to the consumers in a lump-sum fashion.

The working of the system is as follows. The production structure does not possess the decomposition property but sectors 1 and 2 together form a Heckscher-Ohlinsubsystem (HOSS). $r$ is determined from equation (3) as is $W^{*}$ exogenously given. $W$ and $R$ are obtained from equations (1) and (2) as functions of $P_{2} . X_{3}$ is found from (5) as $W^{*}$ and $r$ are known. Inserting the value of $X_{3}$ into (7) and solving simultaneously with equation (4) one can obtain $X_{1}$ and $X_{2}$ in terms of $P_{2}$. From equations (10), (11) and (12.2), $D_{3}, M$ and $Y$ are found. As $X_{2}$ and $Y$ have already been obtained in terms of $P_{2}$, the equilibrium value of $P_{2}$ is obtained from (9). Once $P_{2}$ is known the equilibrium values of all endogenous variables, except, $L_{U}$ are known. Finally, $L_{U}$ is determined from equation (6).

The demand side of the model is represented by a quasi-concave social utility function. Let $U$ denote the social utility that depends on the consumption demands for the three commodities ${ }^{5}$ denoted by, $D_{1}, D_{2}$ and $D_{3}$. Thus, it is shown as

\footnotetext{
4 In an H-T framework, the average wage of labour in the economy is equal to the rural sector wage. This special property is called the 'envelope property'.

5 All the three sectors produce final commodities in this model.
} 


$$
U=U\left(D_{1}, D_{2}, D_{3}\right)
$$

The balance of trade equilibrium requires that

$$
D_{1}+P_{3} D_{3}=X_{1}+P_{3} X_{3},
$$

or equivalently,

$$
D_{1}+P_{2} D_{2}+P_{3}^{*} D_{3}=X_{1}+P_{2} X_{2}+P_{3}^{*} X_{3}+t P_{3} M
$$

Note that commodity 2 is a non-traded final consumption good. So, we have $D_{2}=X_{2}$ in equilibrium.

\section{COMPARATIVE STATICS}

In this section of the paper, we shall analyze the consequences of a policy of labour market reform on the competitive rural wage, national welfare and the problem of unemployment in the urban area of the economy. The unionized wage is positively related to the bargaining strength of the trade unions which is, however, amenable to policy measures. If the government undertakes measures e.g. partial or complete ban on resorting to strikes by the trade unions, reformation of employment security laws to curb union power, the unionized wage falls. ${ }^{6}$ Thus, labour market reform in this paper is captured in terms of an exogenous reduction in the unionized wage, $W^{*}$.

\subsection{Labour market reform, competitive wage and welfare}

Owing to a policy of labour market reform, the unionized urban wage, $W^{*}$, decreases. The return to capital, $r$, rises to satisfy the zero-profit condition for the urban sector (see equation 3). Urban producers now adopt less capital-intensive technique of production than before leading to a decrease in the capital-output ratio, $a_{K 3}$ and an increase in the labour-output ratio, $a_{L 3}$. As capital is specific to sector 3 , a fall in $a_{K 3}$ implies an expansion of the urban sector, both in terms of output and employment. From equations (3) and (5), the expressions for changes in $r$ and $X_{3}$ can be written as follows.

$$
\begin{gathered}
\hat{r}=-\left(\theta_{L 3} / \theta_{K 3}\right) \hat{W}^{*} ; \text { and }, \\
\hat{X}_{3}=-\left(S_{K L}^{3} / \theta_{K 3}\right) \hat{W}^{*}
\end{gathered}
$$

The other two factor prices, $W$ and, $R$, are indirectly affected due a decrease in the unionized wage through a change in the price of the non-traded final commodity, $P_{2}$. Differentiating equations (1) and (2) and solving we get

$$
\begin{gathered}
\hat{W}=-\left(\theta_{N 1} /|\theta|\right) \hat{P}_{2} ; \text { and }, \\
\hat{R}=\left(\theta_{L 1} /|\theta|\right) \hat{P}_{2}
\end{gathered}
$$

\footnotetext{
6 Many of the developing countries, including India, are now seriously thinking in implementing labour market reforms. But, not much progress has been made so far toward implementation of such a highly politically sensitive measure and hence the outcome of this on the unionized wage cannot be statistically established a priori. However, it follows logically that such a move is likely to lower the unionized wage. See footnote 3 for details.
} 
where $|\theta|=\left(\theta_{L 1} \theta_{N 2}-\theta_{L 2} \theta_{N 1}\right)<0$ as sector 2 is more labour-intensive relative to sector 1.

Totally differentiating equations (4) and (7) and using (15.1) and (15.2) we have the following two expressions, respectively. ${ }^{7}$

$$
\begin{gathered}
\lambda_{N 1} \hat{X}_{1}+\lambda_{N 2} \hat{X}_{2}=A_{1} \hat{P}_{2} \\
\lambda_{L 1} \hat{X}_{1}+\lambda_{L 2} \hat{X}_{2}=-A_{2} \hat{P}_{2}-A_{3} \hat{W}^{*}
\end{gathered}
$$

where

$$
\begin{aligned}
& A_{1}=(1 /|\theta|)\left[\left(\lambda_{N 1} S_{N L}^{1}+\lambda_{N 2} S_{N L}^{2}\right)\right]<0 ; \\
& A_{2}=(1 /|\theta|)\left[\lambda_{L 1} S_{L N}^{1}+\lambda_{L 2} S_{L N}^{2}+\left(\theta_{N 1} W^{*} \lambda_{L 3} / W\right)\right]<0 ; \text { and }, \\
& A_{3}=\left(W^{*} \lambda_{L 3} / W \theta_{K 3}\right)\left(\theta_{K 3}-S_{L K}^{3}-S_{K L}^{3}\right)
\end{aligned}
$$

We now define $S_{j k}^{i}$ s. Here $S_{j k}^{i}$ is the degree of substitution between factors in sector $i, i=1,2,3$. For example, $S_{L L}^{1} \equiv\left(W / a_{L 1}\right)\left(\partial a_{L 1} / \partial W\right) ; S_{L N}^{1} \equiv\left(R / a_{L 1}\right)\left(\partial a_{L 1} / \partial R\right)$ with $S_{j k}^{i}>0$ for $j \neq k$; and, $S_{j j}^{i}<0$. We note that as the production functions are homogeneous of degree one, the factor coefficients, $a_{j i}$ s would be homogeneous of degree zero in the factor prices. Therefore, the sum of elasticities for any factor of production in any sector with respect to factor prices must be zero. For example, for labour in sector 1 we have $\left(S_{L L}^{1}+S_{L N}^{1}\right)=0$. All other mathematical terms have already been defined in section 2 , immediately before the formal presentation of the model.

Solving (16) and (17) by Cramer's rule we obtain ${ }^{8}$

$$
\hat{X}_{2}=-(1 /|\lambda|)\left[\left(\lambda_{L 1} A_{1}+\lambda_{N 1} A_{2}\right) \hat{P}_{2}+\lambda_{N 1} A_{3} \hat{W}^{*}\right]
$$

where: $|\lambda|=\left(\lambda_{N 1} \lambda_{L 2}-\lambda_{N 2} \lambda_{L 1}\right)>0$ as sector 1 less labour-intensive vis-à-vis sector 2.

Now differentiating equations (8), (11) and (12.2) and using (15.1) and (15.2) we obtain: ${ }^{9}$

$$
\begin{aligned}
\hat{D}_{2}= & \hat{P}_{2}\left[E_{P 2}^{2}+\left(E_{Y}^{2} V / Y\right)\left\{(1 /|\theta|)\left(R N \theta_{L 1}-W L \theta_{N 1}\right)+t P_{3} P_{2}\left(\partial D_{3} / \partial P_{2}\right)\right\}\right] \\
& +\hat{W}^{*}\left[\left(E_{Y}^{2} V / \theta_{K 3} Y\right)\left(t P_{3} X_{3} S_{K L}^{3}-r K \theta_{L 3}\right)\right]
\end{aligned}
$$

As commodity 2 is non-traded, its market must clear domestically and the comparative static exercises are meaningful only if the equilibrium in the market for commodity 2 is stable. The stability of equilibrium in the market for commodity 2 requires that: ${ }^{10}$

$\left(\hat{D}_{2} / \hat{P}_{2}\right)-\left(\hat{X}_{2} / \hat{P}_{2}\right)<0$. Using (19) and (20) the stability condition can be rewritten as follows.

7 See Appendix I for derivations.

8 This has been derived in Appendix I.

9 See Appendix I for detail derivation.

10 The derivation of the stability condition has been presented in Appendix II. 


$$
\begin{aligned}
\left(\hat{D}_{2} / \hat{P}_{2}\right)-\left(\hat{X}_{2} / \hat{P}_{2}\right)=[ & E_{P 2}^{2}+\left(E_{Y}^{2} V / Y\right)\left\{(1 /|\theta|)\left(R N \theta_{L 1}-W L \theta_{N 1}\right)\right. \\
& \left.\left.+t P_{3} P_{2}\left(\partial D_{3} / \partial P_{2}\right)\right\}\right] \\
& +(1 /|\lambda|)\left[\left(\lambda_{L 1} A_{1}+\lambda_{N 1} A_{2}\right)\right]=\Delta<0 .
\end{aligned}
$$

In equilibrium, the demand for commodity 2 must equal its supply. Differentiating equations (9), (11) and (12.2), using (15.1), (15.2), (19)-(21) and simplifying one gets: ${ }^{11}$

$$
\begin{aligned}
\hat{P}_{2}= & -\left(\hat{W}^{*} / \Delta\right)\left[\left(E_{Y}^{2} V P_{3}^{*} X_{3} / \theta_{K 3} Y\right)\left\{\left(t S_{K L}^{3} / 1+t\right)-\left(\theta_{K 3} \theta_{L 3}\right)\right\}\right. \\
& \left.+\left\{\left(\lambda_{N 1} W^{*} \lambda_{L 3} /|\lambda| W \theta_{K 3}\right)\left(\theta_{K 3}-S_{L K}^{3}-S_{K L}^{3}\right)\right\}\right]
\end{aligned}
$$

As $\Delta<0$ (see (21)) from (22) it is easy to check that $\hat{P}_{2}>0$ when $\hat{W}^{*}<0$ under the sufficient condition: ${ }^{12}$

$$
\left[\left\{\theta_{K 3} \theta_{L 3}(1+t) / t\right\} \geq S_{K L}^{3} \geq \theta_{K 3}\right]
$$

Now from (15.2), we find that $\hat{W}>0$ and $\hat{R}<0$ when $\hat{W}^{*}<0$ under the sufficient condition, as stated above. This leads to the following proposition.

Proposition 1. If $\left[\left\{\theta_{K 3} \theta_{L 3}(1+t) / t\right\} \geq S_{K L}^{3} \geq \theta_{K 3}\right]$, a policy of labour market reform leads to: (i) an increase in the rural wage rate; (ii) a decrease in the return to land-capital; and, (iii) an increase in the price of the non-traded final commodity.

We explain proposition 1 as follows. As the rural sector wage, $W$, and the return to land-capital, $R$, depend on the price of the non-traded commodity, $P_{2}$, let us first see how labour market reform affects $P_{2}$. A policy of labour market reform resulting in a decrease in the unionized wage, $W^{*}$, raises the return to capital, $r$, to satisfy the zeroprofit condition for sector 3 (see equation 3 ). As the $\left(W^{*} / r\right)$ ratio falls, the producers in the urban sector adopt less capital-intensive technique of production than before leading to a decrease in the capital-output ratio, $a_{K 3}$ and an increase in the labour-output ratio, $a_{L 3}$. As capital is specific to sector 3 , a fall in $a_{K 3}$ and an increase in $a_{L 3}$ imply an expansion of the urban sector, both in terms of output and employment. Thus, there are two opposite effects on the expected wage rate in the urban sector. It falls as the unionized wage, $W^{*}$, falls while it rises as the level of employment in the urban sector rises. The expected urban wage actually increases if $S_{K L}^{3} \geq \theta_{K 3}$ and /or $S_{K L}^{3} \geq \theta_{K 3}$. If this happens, there would be a fresh migration from the rural to the urban sector. This lowers the supply of labour to the two rural sectors (HOSS). As a consequence, sector 2 (sector 1) contracts (expands) following a Rybczynski type effect as sector 2 is more labour-intensive relative to sector 1 . As the supply of the non-traded commodity produced by sector 2 decreases given its demand, its price, $P_{2}$ should increase in order to satisfy the demand-supply equality condition (equation 9). On the other hand, as sector 3 expands the volume of import of commodity 3 falls and this lowers the tariff revenue. Besides, the aggregate capital income has increased following an increase in the rate of return to capital, $r$. If the latter effect dominates over the former, the

11 This is shown in Appendix I.

12 One may check that this result holds under a few alternative sufficient conditions as well. 
national income at domestic prices, $Y$, rises, other things remaining unchanged. ${ }^{13}$ This happenes if $\left(\left(t S_{K L}^{3} / 1+t\right) \leq \theta_{K 3} \theta_{L 3}\right)$. This raises the demand for commodity 2 and, therefore, exerts an upward pressure on $P_{2}$, given the supply of good 2 . All these will be quite clear if one looks at equation (22). The terms in the first pair of curly-brackets in the right-hand side denote the demand side effects while those in the other represent the supply side effects on $P_{2}$. If the sufficient conditions as stated above hold both the demand supply effects work in the same direction and lead to an increase in $P_{2}$. Then, an increase in $P_{2}$ produces a Stolper-Samuelson effect in the HOSS leading to an increase in the rural wage, $W$, and a decrease in the return to land-capital, $R$, as sector 2 is more labour-intensive vis-à-vis sector 1 .

To analyze the welfare implication of labour market reform totally differentiating equations (13) and (14.1) and using (15.2) we get: ${ }^{14}$

$$
\begin{aligned}
\left(1 / U_{1}\right) & \left(d U / d W^{*}\right) \\
= & V\left[\left(L_{3}+L_{U}\right)\left(d W / d W^{*}\right)+t P_{3}\left\{\left(\partial D_{3} / \partial P_{2}\right)+X_{2}\left(\partial D_{3} / \partial Y\right)\right\}\left(d P_{2} / d W^{*}\right)\right. \\
& (+) \quad(-) \quad(+) \\
& \left.-\left(P_{3}^{*} X_{3} / \theta_{K 3} W^{*}\right)\left\{\left(\theta_{L 3} \theta_{K 3}\right)-\left(t S_{K L}^{3} / 1+t\right)\right\}\right]
\end{aligned}
$$

From (24) it is easy to verify that $\left(1 / U_{1}\right)\left(d U / d W^{*}\right)<0$ under the sufficient condition ${ }^{15}$ that: $\left[\theta_{K 3} \theta_{L 3}(1+t) / t \geq S_{K L}^{3} \geq \theta_{K 3}\right]$. This establishes the following proposition.

PROPOSITION 2. In an economy with a non-traded backward agricultural sector and a tariff-protected import-competing sector, a policy of labour market reform that lowers the unionized urban wage improves social welfare if $\left[\left\{\theta_{K} \theta_{L 3}(1+t) / t\right\} \geq\right.$ $\left.S_{K L}^{3} \geq \theta_{K 3}\right]$.

A policy of labour market reform that lowers the unionized urban wage produces three effects on welfare in this model. First, the competitive rural wage and the return to capital increase while the rental to land-capital decreases. ${ }^{16}$ The amount of tariff revenue which the consumers receive as transfer payments also changes. However, under the sufficient condition as presented above, the net effect of all these would be an

\footnotetext{
13 There will be only two effects on $Y$ so long as the price of the non-traded commodity, $P_{2}$, remains unaltered. Subsequently, $P_{2}$ will change as the demand and supply of the non-traded commodity change that, in turn, changes the rural sector wage, the return to land-capital and the tariff revenue and hence $Y$ once more. All these have been discussed further in the discussions of the welfare consequence of labour market reform (proposition 2).

14 This has been derived in Appendix III.

15 If the technology in sector 3 (urban sector) is of the fixed-coefficient type i.e. if $S_{j i}^{3}=0$ for $j, i=L, K$, it is easy to check that $\left(1 / U_{1}\right)\left(d U / d W^{*}\right)<0$ under the sufficient condition: $\left(E_{Y}^{2} V W L / Y\right)>\left(\lambda_{N 1} /|\lambda|\right)$.

16 See proposition $I$ and the subsequent discussions.
} 
increase in the national income at domestic prices $^{17}$ and this produces a positive effect on welfare. Secondly, as the price of the non-traded final commodity $\left(P_{2}\right)$ rises, the relative domestic price of the importables (in terms of $P_{2}$ ) falls. This leads to an increase in the demand for the importables as different commodities are substitutes to the consumers. Besides, the increase in income national at domestic prices also raises the demand for commodity 3. So, both these effects push up the import demand. This causes welfare to improve as the demand side distortionary cost of tariff falls. Finally, a reduction in the unionized urban wage leads to an increase in the domestic production of commodity 3 and hence lowers the import demand. Thus, the allocation of economic resources becomes more inefficient and the cost of tariff protection of the supply side increases which works negatively on welfare. The net result of all these three effects would be an increase in social welfare if the first two positive effects together are stronger than the third effect. This is actually the case and social welfare indeed improves if $\left[\left\{\theta_{K 3} \theta_{L 3}(1+t) / t\right\} \geq S_{K L}^{3} \geq \theta_{K 3}\right]$ which is quite clear from our verbal explanation of proposition 1. It may be mentioned that in the absence of any tariff, only the first effect exists and welfare improves unambiguously due to labour market reform.

\subsection{Labour market reform and urban unemployment}

We are now going to analyze the consequence of labour market reform on the problem of urban unemployment.

Subtraction of (6) from (7) yields

$$
L_{U}=\left[\left\{\left(W^{*} / W\right)-1\right\} a_{L 3} X_{3}\right]
$$

Totally differentiating equation (25), using (15.1) and (25) and simplifying one can derive the following expression. ${ }^{18}$

$$
\begin{aligned}
\left(\hat{L}_{U} / \hat{W}^{*}\right)= & {\left[\left\{\left(\lambda_{L 3}+\lambda_{L U}\right) / \lambda_{L U}\right\}\right.} \\
& (+) \\
& \left.-\left\{\left(S_{L K}^{3}+S_{K L}^{3}\right) / \theta_{K 3}\right\}\right]-\left[\left\{\left(\lambda_{L 3}+\lambda_{L U}\right) / \lambda_{L U}\right\}\left(\hat{W} / \hat{W}^{*}\right)\right] \\
& (+) \quad(+)
\end{aligned}
$$

Using (15.2) and (23) from (26) one can infer that $\hat{L}_{U}<0$ when $\hat{W}^{*}<0$ under the following two sufficient conditions: ${ }^{19}$ (i) $\left[\theta_{K 3} \theta_{L 3}(1+t) / t \geq S_{K L}^{3} \geq \theta_{K 3}\right]$; and (ii) $\left[\left\{\left(\lambda_{L 3}+\lambda_{L U}\right) / \lambda_{L U}\right\} \geq\left\{\left(S_{L K}^{3}+S_{K L}^{3}\right) / \theta_{K 3}\right\}\right]$. This leads to the final proposition of the model.

17 We have already explained as to how a decrease in $W^{*}$ leads to an increase in $Y$ at given $P_{2}$ under the sufficient conditions as stated in proposition 1 . Now as $P_{2}$ rises $W$ rises and $R$ falls. But, the magnitube of increase in aggregate wage income would be greater than the amount of decrease in aggregate rental income to land-capital as sector 2 is more labour-intensive relative to sector 1 . Besides, an increase in $P_{2}$ raises the import-demand for commodity 3 by lowering the relative domestic price of commodity 3 . This raises the tariff-revenue. From all these, we find that the national income at domestic prices, $Y$, rises under the sufficient conditions as stated above.

18 See Appendix IV for its derivation.

19 If the technology in sector 3 (urban sector) is of the fixed-coefficient type, one can verify that $\left(d L_{U} / d W^{*}\right)>0$ under the sufficient condition: $\left(E_{Y}^{2} V W L / Y\right)>\left(\lambda_{N 1} /|\lambda|\right)$. 
PROPOSITION 3. A policy of labour market reform lowers the level of urban unemployment if (i) $\left[\left\{\theta_{K 3} \theta_{L 3}(1+t) / t\right\} \geq S_{K L}^{3} \geq \theta_{K 3}\right]$; and (ii) $\left[\left\{\left(\lambda_{L 3}+\lambda_{L U}\right) / \lambda_{L U}\right\} \geq\right.$ $\left.\left\{\left(S_{L K}^{3}+S_{K L}^{3}\right) / \theta_{K 3}\right\}\right]$.

We explain proposition 3 in the following manner. In the migration equilibrium the expected urban wage for a prospective rural migrant equals the actual rural wage. A policy of labour market reform affects the migration equilibrium in three ways. First, the unionized urban wage decreases. This lowers the expected urban wage. Secondly, the urban sector expands both in terms of output and employment as producers adopt a less capital-intensive technique of production than before and capital is specific to this sector. As the number of jobs available in the urban sector increases, it raises the expected urban wage. Hence, there are two opposite effects on the expected urban wage, The net effect would be an increase in the expected urban wage if $S_{K L}^{3} \geq \theta_{K 3}$ and/or $S_{L K}^{3} \geq \theta_{K 3}$. This paves the way for fresh migration from the rural to the urban sector. This net effect may be termed as the centrifugal force that drives the rural workers to move away from the rural sector. If the rural sector wage remains unchanged, the number of ner jobs created in the urban sector falls short of the number of new migrants into the urban sector and the unemployment problem in the urban area aggravates. Finally, owing to a reduction in the unionized urban wage, the price of the non-traded commodity rises under the sufficient condition, $\left[\left\{\theta_{K 3} \theta_{L 3}(1+t) / t\right\} \geq S_{K L}^{3} \geq \theta_{K 3}\right]$, and leads to an increase in the competitive rural wage (see proposition 1). This we may call the centripetal force that prevents rural workers from migrating into the urban sector. Thus, there are three different effects working on determination of the size of the unemployed urban workforce. If the latter effect outweighs the net effect of the first two, the level of urban unemployment falls. This happens if $\left[\left\{\left(\lambda_{L 3}+\lambda_{L U}\right) / \lambda_{L U}\right\} \geq\left\{\left(S_{L K}^{3}+S_{K L}^{3}\right) / \theta_{K 3}\right\}\right]$.

\section{CONCLUding Remarks}

After essentially satisfactory progress in implementation of trade and investment reforms, many of the developing countries including India are presently thinking about undertaking labour market reforms. But, the policymakers are hesitating to implement measures like partial or complete ban on resorting to strikes by the trade unions, reformation of employment security laws to curb union power on the apprehension that any such attempt would be vehemently opposed by trade unions and opposition political parties. A populist belief by the trade unions is that policies pertaining to labour market reform would lead to a general reduction in the unskilled wages and make all the common (unskilled) workers worse off. This paper has made an attempt to examine whether the ominous apprehensions about labour market reform are based upon any solid theoretical foundations using a three sector HT model with agricultural dualism and a non-traded final commodity. The analysis of the present paper finds that labour market reform is likely to be welfare-improving and may not aggravate the problem of urban unemployment in the given setup. In the presence of agricultural dualism and a non-traded final agricultural commodity, the aggregate factor income and the demand 
for importables increase. The aggregate effect of these two may outweigh the deadweight loss caused by the protectionist policy on the economy. The competitive rural wage increases and may lower the problem of urban unemployment. Therefore, this theoretical framework may be useful in explaining as to why labour market reform forms an integral constituent of the liberalized economic package in the liberalizing countries.

\section{REFERENCES}

Bardhan, P. K. (1973): 'A model of growth of capitalism in a dual agrarian economy', in: Bhagwati, J. M., Eckaus, R. S. (Eds.), Development and Planning: Essays in Honour of Paul Rosenstein-Rodan. USA, MIT Press.

Bhalotra, S. (2002): 'The impact of economic liberalization on employment and wages in India', ILO, Geneva.

Chaudhuri, S. (2003): 'How and how far to liberalize a developing country with informal sector and factor market distortions', Journal of International Trade and Economic Development 12(4), 403-428.

Harris, J. R. and Todaro, M. (1970): 'Migration, unemployment, and development: a two-sector analysis', American Economic Review 60, 126-142.

\section{Mathematical APPENDiCES}

APPENDIX I: DETAILED DERIVATIONS OF DIFFERENT EXPRESSIONS

In this paper, we are interested to analyze the effects of labour market reform only. Labour market reform here is captured by a reduction in the unionized wage, $W^{*}$ All other parameters are assumed to be unchanged.

Differentiating equation (3) one gets:

$$
\theta_{L 3} \hat{W}^{*}+\theta_{K 3} \hat{r}=0
$$

From (A.1) one can write:

$$
\hat{r}=-\left(\theta_{L 3} / \theta_{K 3}\right) \hat{W}^{*}
$$

Now differentiating (5) we obtain:

$$
\left(S_{K L}^{3} \hat{W}^{*}+S_{K K}^{3} \hat{r}\right)+\hat{X}_{3}=0
$$

Inserting the value of $\hat{r}$ into (A.2) and using $\left(S_{K L}^{3}+S_{K K}^{3}\right)=0$, we find:

$$
\hat{X}_{3}=-\left(S_{K L}^{3} / \theta_{K 3}\right) \hat{W}^{*}
$$

Using (11) from (12.2) we can write:

$$
Y=W L+R N+r K+t P_{3}\left[D_{3}\left(P_{2}, P_{3}^{*}, Y\right)-X_{3}\right]
$$

Total differentiation of (A.3) yields

$$
\begin{aligned}
& d Y=L d W+N d R+K d r+t P_{3}\left\{\left(\partial D_{3} / \partial P_{2}\right) d P_{2}+\left(\partial D_{3} / \partial Y\right) d Y-d X_{3}\right\} \\
& \text { or, } d Y\left(1-t P_{3} \partial D_{3} / \partial Y\right)=L d W+N d R+K d r+t P_{3}\left(\partial D_{3} / \partial P_{2}\right) d P_{2}-t P_{3} d X_{3} \\
& \text { or, } d Y\left(1-t m_{3} /(1+t)\right)=L d W+N d R+K d r+t P_{3}\left(\partial D_{3} / \partial P_{2}\right) d P_{2}-t P_{3} d X_{3} \\
& \text { or, } \hat{Y}=(V / Y)\left[W L \hat{W}+R N \hat{R}+r K \hat{r}+t P_{3} P_{2}\left(\partial D_{3} / \partial P_{2}\right) \hat{P}_{2}\right. \\
& \left.\quad+t P_{3} X_{3}\left(S_{K L}^{3} / \theta_{K 3}\right) \hat{W}^{*}\right]
\end{aligned}
$$


where $V=\left[(1+t) /\left\{1+t\left(1-m_{3}\right)\right\}\right]>0$; and, $m_{3}=\left(P_{3}^{*} \partial D_{3} / \partial Y\right)$ is the marginal propensity to consume commodity 3 , and $1>m_{3}>0$.

Now, totally differentiating equation (4) one gets

$$
\lambda_{N 1} \hat{X}_{1}+\lambda_{N 2} \hat{X}_{2}=-\lambda_{N 1}\left(S_{N L}^{1} \hat{W}+S_{N N}^{1} \hat{R}\right)-\lambda_{N 2}\left(S_{N L}^{2} \hat{W}+S_{N N}^{2} \hat{R}\right)
$$

Using (15.2) and simplifying the above expression can be rewritten as follows.

$$
\lambda_{N 1} \hat{X}_{1}+\lambda_{N 2} \hat{X}_{2}=A_{1} \hat{P}_{2}
$$

where: $A_{1}=\left[\lambda_{N 1} S_{N L}^{1}+\lambda_{N 2} S_{N L}^{2}\right]>0$.

(Note that $S_{N L}^{1}+S_{N N}^{1}=0=S_{N L}^{2}+S_{N N}^{2}$; and, $\theta_{L 1}+\theta_{N 1}=1=\theta_{L 2}+\theta_{N 2}$.)

Similarly, differentiating equation (7) and using (15.1) one gets:

$$
\begin{aligned}
\lambda_{L 1} \hat{X}_{1}+\lambda_{L 2} \hat{X}_{2}= & -\hat{W}\left[\lambda_{L 1} S_{L L}^{1}+\lambda_{L 2} S_{L L}^{2}-\left(W^{*} \lambda_{L 3} / W\right)\right]-\hat{R}\left[\lambda_{L 1} S_{L N}^{1}+\lambda_{L 2} S_{L N}^{2}\right] \\
& -\hat{W}^{*}\left[\left\{1+S_{L K}^{3}-S_{K L}^{3}\right\}\left(W^{*} \lambda_{L 3} / W\right)\right]
\end{aligned}
$$

Using (15.2) and simplifying, (A.5) can be rewritten as follows.

$$
\lambda_{L 1} \hat{X}_{1}+\lambda_{L 2} \hat{X}_{2}=-A_{2} \hat{P}_{2}-A_{3} \hat{W}^{*}
$$

where:

$$
\begin{aligned}
& A_{2}=(1 /|\theta|)\left[\lambda_{L 1} S_{L N}^{1}+\lambda_{L 2} S_{L N}^{2}+\left(\theta_{N 1} W^{*} \lambda_{L 3} / W\right)\right]<0 ; \text { and, } \\
& A_{3}=\left(W^{*} \lambda_{L 3} / W \theta_{K 3}\right)\left(\theta_{K 3}-S_{L K}^{3}-S_{K L}^{3}\right) .
\end{aligned}
$$

Arranging equations (16) and (17) in a matrix notation we get

$$
\left[\begin{array}{ll}
\lambda_{N 1} & \lambda_{N 2} \\
\lambda_{L 1} & \lambda_{L 2}
\end{array}\right]\left[\begin{array}{l}
\hat{X}_{1} \\
\hat{X}_{2}
\end{array}\right]=\left[\begin{array}{c}
A_{1} \hat{P}_{2} \\
-A_{2} \hat{P}_{2}-A_{3} \hat{W}^{*}
\end{array}\right]
$$

Now solving (A.6) using Cramer's rule and simplifying one can find:

$$
\hat{X}_{2}=-(1 /|\lambda|)\left[\left(\lambda_{L 1} A_{1}+\lambda_{N 1} A_{2}\right) \hat{P}_{2}+\lambda_{N 1} A_{3} \hat{W}^{*}\right]
$$

where: $|\lambda|=\left(\lambda_{N 1} \lambda_{L 2}-\lambda_{N 2} \lambda_{L 1}\right)>0$ as sector 1 less labour-intensive vis-à-vis sector 2.

Now differentiating equation (8) one gets:

$$
\hat{D}_{2}=E_{P 2}^{2} \hat{P}_{2}+E_{Y}^{2} \hat{Y}
$$

Using (A.4), (15.1) and (15.2) and simplifying the above expression can be rewritten as follows.

$$
\begin{aligned}
\hat{D}_{2}= & \hat{P}_{2}\left[E_{P 2}^{2}+\left(E_{Y}^{2} V / Y\right)\left\{\left(R N \theta_{L 1}-W L \theta_{N 1}\right)(1 /|\theta|)+t P_{3} P_{2}\left(\partial D_{3} / \partial P_{2}\right)\right\}\right] \\
& (-) \quad(-) \\
+ & {\left[\left(E_{Y}^{2} V / Y \theta_{K 3}\right)\left(t P_{3} X_{3} S_{K L}^{3}-r K \theta_{L 3}\right)\right] \hat{W}^{*} }
\end{aligned}
$$

In equilibrium, we have:

$$
\hat{D}_{2}=\hat{X}_{2}
$$

Using (19) and (20) from (A.7) one can write: 


$$
\begin{aligned}
\hat{P}_{2}\left[E_{P 2}^{2}\right. & \left.+\left(E_{Y}^{2} V / Y\right)\left\{\left(R N \theta_{L 1}-W L \theta_{N 1}\right)(1 /|\theta|)+t P_{3} P_{2}\left(\partial D_{3} / \partial P_{2}\right)\right\}\right] \\
& +\left[\left(E_{Y}^{2} V / Y \theta_{K 3}\right)\left(t P_{3} X_{3} S_{K L}^{3}-r K \theta_{L 3}\right)\right] \hat{W}^{*} \\
= & -(1 /|\lambda|)\left[\left(\lambda_{L 1} A_{1}+\lambda_{N 1} A_{2}\right) \hat{P}_{2}+\lambda_{N 1} A_{3} \hat{W}^{*}\right]
\end{aligned}
$$

Collecting terms and simplifying one gets:

$$
\begin{aligned}
\hat{P}_{2}= & -\left(\hat{W}^{*} / \Delta\right)\left[\left(E_{Y}^{2} V P_{3}^{*} X_{3} / \theta_{K 3} Y\right)\left\{\left(t S_{K L}^{3} / 1+t\right)-\left(\theta_{K 3} \theta_{L 3}\right)\right\}\right. \\
& \left.+\left\{\left(\lambda_{N 1} W^{*} \lambda_{L 3} /|\lambda| W \theta_{K 3}\right)\left(\theta_{K 3}-S_{L K}^{3}-S_{K L}^{3}\right)\right\}\right]
\end{aligned}
$$

where:

$$
\begin{aligned}
\Delta= & {\left[E_{P 2}^{2}+\left(E_{Y}^{2} V / Y\right)\left\{(1 /|\theta|)\left(R N \theta_{L 1}-W L \theta_{N 1}\right)+t P_{3} P_{2}\left(\partial D_{3} / \partial P_{2}\right)\right\}\right] } \\
& +(1 /|\lambda|)\left[\left(\lambda_{L 1} A_{1}+\lambda_{N 1} A_{2}\right)\right]
\end{aligned}
$$

APPENDIX II: STABILITY CONDITION OF THE MARKET FOR COMMODITY 2

As commodity 2 is internationally non-traded its market must clear domestically through adjustments in its price, $P_{2}$.

The stability condition in the market for commodity 2 requires that $\left(d\left(D_{2}-\right.\right.$ $\left.\left.X_{2}\right) / d P_{2}\right)<0$. This implies around equilibrium, initially, $D_{2}=X_{2}$. Thus,

$$
\left(\left(\hat{D}_{2} / \hat{P}_{2}\right)-\left(\hat{X}_{2} / \hat{P}_{2}\right)\right)<0 \text {. }
$$

From (19) and (20) we can derive the following two expressions, respectively.

$$
\begin{gathered}
\left(\hat{X}_{2} / \hat{P}_{2}\right)=-(1 /|\lambda|)\left(\lambda_{L 1} A_{1}+\lambda_{N 1} A_{2}\right) ; \text { and }, \\
\left(\hat{D}_{2} / \hat{P}_{2}\right)=\left[E_{P 2}^{2}+\left(E_{Y}^{2} V / Y\right)\left\{\left(R N \theta_{L 1}-W L \theta_{N 1}\right)(1 /|\theta|)\right.\right. \\
\left.\left.+t P_{3} P_{2}\left(\partial D_{3} / \partial P_{2}\right)\right\}\right]
\end{gathered}
$$

Using (A.9) and (A.10) from (A.8) one gets:

$$
\begin{aligned}
\left(\hat{D}_{2} / \hat{P}_{2}\right)-\left(\hat{X}_{2} / \hat{P}_{2}\right)= & {\left[E_{P 2}^{2}+\left(E_{Y}^{2} V / Y\right)\left\{(1 /|\theta|)\left(R N \theta_{L 1}-W L \theta_{N 1}\right)\right.\right.} \\
& \left.\left.+t P_{3} P_{2}\left(\partial D_{3} / \partial P_{2}\right)\right\}\right] \\
& +(1 /|\lambda|)\left[\left(\lambda_{L 1} A_{1}+\lambda_{N 1} A_{2}\right)\right]=\Delta<0 .
\end{aligned}
$$

APPENDIX III: THE CHANGE IN WELFARE

Differentiating (13) and (14.1), we have

$$
\begin{aligned}
d U / U_{1} & =d D_{1}+P_{2} d D_{2}+P_{3}^{*} d D_{3} \\
& =d X_{1}+P_{2} d X_{2}+P_{3}^{*} d X_{3}+t P_{3} d M,
\end{aligned}
$$

where $U_{1}=\partial U / \partial D_{1}$.

Differentiating (12.1) we obtain

$$
d Y=\left[d X_{1}+P_{2} d X_{2}+P_{3}^{*} d X_{3}\right]+X_{2} d P_{2}+t P_{3} d M
$$

By differentiating production functions and considering equations (4)-(7), we have 


$$
\begin{aligned}
& {\left[d X_{1}+P_{2} d X_{2}+P_{3}^{*} d X_{3}\right]} \\
& \quad=\left(F_{L}^{1} d L_{1}+F_{N}^{1} d N_{1}\right)+P_{2}\left(F_{L}^{2} d L_{2}+F_{N}^{2} d N_{2}\right)+P_{3}^{*}\left(F_{L}^{3} d L_{3}+F_{K}^{3} d K\right) \\
& \quad=\left(W d L_{1}+R d N_{1}\right)+\left(W d L_{2}+R d N_{2}\right)+\left(W^{*} d L_{3}+r d K\right) \\
& \quad=\left(L_{3}+L_{U}\right) d W-L_{3} d W^{*}
\end{aligned}
$$

[Note that $d N_{1}+d N_{2}=0$; and, $d K=0 . P_{i} F_{j}^{i}$ is the value of marginal product of the $j$ th factor in the $i$ th sector, which is equal to the factor price.]

Using (A.12) and (A.13) we can write:

$$
d Y=\left(L_{3}+L_{U}\right) d W-L_{3} d W^{*}+X_{2} d P_{2}+t P_{3} d M
$$

Differentiating equation (11) and using (A.14), we obtain

$$
\begin{aligned}
d M= & \left(\partial D_{3} / \partial P_{2}\right) d P_{2}+\left(\partial D_{3} / \partial Y\right)\left[\left(L_{3}+L_{U}\right) d W\right. \\
& \left.-L_{3} d W^{*}+X_{2} d P_{2}+t P_{3} d M\right]-d X_{3} \\
\text { or } d M= & \left(\partial D_{3} / \partial P_{2}\right) d P_{2}+\left(m_{3} / P_{3}^{*}\right)\left[\left(L_{3}+L_{U}\right) d W\right. \\
& \left.-L_{3} d W^{*}+X_{2} d P_{2}+t P_{3} d M\right]-d X_{3}
\end{aligned}
$$

where $m_{3}=P_{3}^{*}\left(\partial D_{3} / \partial Y\right)$ is the marginal propensity to consume commodity 3 .

Arranging terms one gets

$$
\begin{aligned}
d M= & V\left[\left(\partial D_{3} / \partial P_{2}\right) d P_{2}+\left(m_{3} / P_{3}^{*}\right)\left\{\left(L_{3}+L_{U}\right) d W-L_{3} d W^{*}+X_{2} d P_{2}\right\}\right. \\
& \left.-d X_{3}\right]
\end{aligned}
$$

where $V=\left[(1+t) /\left\{1+t\left(1-m_{3}\right)\right\}\right]>0$.

Using (A.13) and (A.15) from (A.11) we find

$$
\begin{gathered}
\left(d U / U_{1}\right)=\left[d W\left(L_{3}+L_{U}\right)-L_{3} d W^{*}\right]\left\{1+\left(t m_{3} V / 1+t\right)\right\}+t P_{3} V\left\{\left(\partial D_{3} / \partial P_{2}\right)\right. \\
\left.+X_{2}\left(\partial D_{3} / \partial Y\right)\right\} d P_{2}-t P_{3} V d X_{3} \\
\text { or, }\left(1 / U_{1}\right)\left(d U / d W^{*}\right)= \\
(+) \quad\left(\left(L_{3}+L_{U}\right)\left(d W / d W^{*}\right)+t P_{3}\left\{\left(\partial D_{3} / \partial P_{2}\right)\right.\right. \\
(-) \quad(+) \\
\left.+X_{2}\left(\partial D_{3} / \partial Y\right)\right\}\left(d P_{2} / d W^{*}\right) \\
(+) \quad(-)
\end{gathered}
$$

[Note that: $L_{3}=a_{L 3} X_{3}$; and, $\left\{1+\left(t m_{3} V / 1+t\right)\right\}=V$.]

APPENDIX IV: DeRIVATION OF EQUATION 26

Totally differentiating equation (25) we get:

$$
d L_{U}=a_{L 3} X_{3}\left[\left(W^{*} / W\right)\left(\hat{W}^{*}-\hat{W}\right)+\left\{\left(W^{*} / W\right)-1\right\}\left(\hat{a}_{L 3}+\hat{X}_{3}\right)\right]
$$




$$
\text { or, } \begin{aligned}
\lambda_{L U} \hat{L}_{U}= & \lambda_{L 3}\left[\left(W^{*} / W\right)\left(\hat{W}^{*}-\hat{W}\right)+\left\{\left(W^{*} / W\right)-1\right\}\right. \\
& \left.\times\left(S_{L L}^{3} \hat{W}^{*}+S_{L K}^{3} \hat{r}+\hat{X}_{3}\right)\right]
\end{aligned}
$$

where $\lambda_{L U}=\left(L_{U} / L\right) ;$ and, $\lambda_{L 3}=\left(a_{L 3} X_{3} / L\right)$.

Using (15.1) one can rewrite (A.16) as follows.

$$
\begin{aligned}
\lambda_{L U} \hat{L}_{U}= & \lambda_{L 3}\left[\left(W^{*} / W\right)\left(\hat{W}^{*}-\hat{W}\right)+\left\{\left(W^{*} / W\right)-1\right\}\left\{S_{L L}^{3} \hat{W}^{*}-\left(\theta_{L 3} / \theta_{K 3}\right) S_{L K}^{3} \hat{W}^{*}\right.\right. \\
& \left.\left.-\left(S_{K L}^{3} / \theta_{K 3}\right) \hat{W}^{*}\right\}\right]
\end{aligned}
$$

Collecting terms and simplifying one can write:

$$
\hat{L}_{U}=\hat{W}^{*}\left[\left(W^{*} \lambda_{L 3} / W \lambda_{L U}\right)-\left\{\left(S_{L K}^{3}+S_{K L}^{3}\right) / \theta_{K 3}\right\}\right]-\left(W^{*} \lambda_{L 3} / W \lambda_{L U}\right) \hat{W}
$$

Now from (25) it is easy to obtain:

$$
\begin{aligned}
& \lambda_{L U}=\left\{\left(W^{*} / W\right)-1\right\} \lambda_{L 3} \\
& \text { or, }\left(W^{*} \lambda_{L 3} / W \lambda_{L U}\right)=\left\{\left(\lambda_{L 3}+\lambda_{L U}\right) / \lambda_{L U}\right\}
\end{aligned}
$$

Using (A.18) one can rewrite (A.17) as follows.

$$
\begin{aligned}
\left(\hat{L}_{U} / \hat{W}^{*}\right)=\left[\left\{\left(\lambda_{L 3}+\lambda_{L U}\right) / \lambda_{L U}\right\}\right. & \left.-\left\{\left(S_{L K}^{3}+S_{K L}^{3}\right) / \theta_{K 3}\right\}\right] \\
(+) & (+) \\
& -\left[\left\{\left(\lambda_{L 3}+\lambda_{L U}\right) / \lambda_{L U}\right\}\left(\hat{W} / \hat{W}^{*}\right)\right] \\
& (+)
\end{aligned}
$$

